\section{Historical Trends in Strawberry Fruit Quality Revealed by a Trial of University of Florida Cultivars and Advanced Selections}

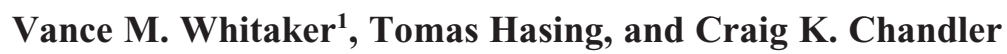 \\ Gulf Coast Research and Education Center, University of Florida, 14625 CR \\ 672, Wimauma, FL 33598
}

\section{Anne Plotto and Elizabeth Baldwin USDA-ARS, Citrus and Subtropical Products Lab, 600 Avenue S, NW, Winter Haven, FL 33881}

Additional index words. fruit breeding, fruit color, organic acids, soluble solids content, sugars, titratable acidity

\begin{abstract}
The University of Florida strawberry (Fragaria $\times$ ananassa Duch. ex Rosier) breeding program has maintained a continuous breeding effort since 1968 to develop cultivars that are highly adapted to winter production in west-central Florida. To gain insight into breeding progress over time, two advanced selections (UF1 and UF2) and 10 released cultivars, from Florida Belle (1975) to Florida Radiance (2008), were compared for various fruit quality traits in a two-location field study during the 2009-2010 season. Fruit size varied dramatically from $30.8 \mathrm{~g}$ for 'Elyana' to $16.2 \mathrm{~g}$ for 'Dover' at Balm, FL, and from $28.3 \mathrm{~g}$ for UF2 to $\mathbf{1 6 . 6} \mathrm{g}$ for 'Dover' at Dover, FL. A linear regression of fruit size on year of release revealed an average gain of $2.6 \mathrm{~g}$ per year since 1975 for the cultivars and selections tested $\left(R^{2}=0.44\right)$. A similar analysis revealed a reduction over time in the proportion of cull fruit $\left(R^{2}=0.30\right)$. Gains were apparent for the redness of the internal flesh, from a colorimeter a* value of 16.1 for 'Florida Belle' (1975) to 34.7 for 'Carmine' (2002) but were not sustained for later releases and selections. Although there were significant differences among genotypes for all chemical traits affecting flavor, there were no discernable patterns over time. There were wide month-to-month variations in individual sugars and organic acids, except for citric acid, which was stable across months and locations. The ratio of soluble solids content to titratable acidity ranged widely among genotypes, from a high of 15.7 for 'Florida Belle' in February at Dover, FL, to a low of 6.4 for 'Winter Dawn' in January at Balm, FL. The observed variability and trends in fruit quality traits will help guide future genetic studies and inform decisions about future breeding priorities and selection procedures.
\end{abstract}

The University of Florida (UF) strawberry (Fragaria $\times$ ananassa) breeding program develops cultivars adapted for winter fruit production in west-central Florida. This region is the second leading production area in the United States behind coastal California with a harvested area of $\approx 9000$ acres and a crop valued at \$313 million during the 2010-2011 season (http://www.nass.gov). A continuous breeding effort has existed since 1968. The University of Florida has released 10 cultivars during this period. Dr. Charles Howard released 'Florida Belle' (1975) and 'Dover' (1979). Dr. Craig K. Chandler released 'Sweet Charlie' (1992) (Chandler et al., 1997a), 'Rosa Linda' (1996) (Chandler et al., 1997b), 'Earlibrite' (2000) (Chandler et al., 2000a), 'Strawberry Festival' (2000)

Received for publication 6 Jan. 2011. Accepted for publication 26 Jan. 2011.

We acknowledge Catalina Moyer, Yanina Perez, and James Sumler for assistance in data collection. ${ }^{1}$ To whom reprint requests should be addressed; e-mailvwhitaker@ufl.edu. as variation in SSC, TA, and volatile components (Jouquand et al., 2008).

Retrospective analyses have been conducted for a number of crops to evaluate genetic progress over time for important traits. For example, a field study of cotton cultivars released between 1918 and 1982 showed steady linear increases for some traits, whereas other traits showed improvement early in the breeding program but experienced a plateau in later generations. Still other traits were variable among cultivars but exhibited no discernable trend over time (Bayles et al., 2005). Shaw and Larson (2008) compared two sets of cultivars released from the University of California-Davis strawberry breeding program from 1945-1966 and from 1993-2004 showing significant progress for fruit size, yield, and appearance. Approximate selection responses for the different traits ranged from $1 \%$ to $3 \%$ per year.

The purpose of this study was to evaluate relevant fruit quality attributes of UF strawberry cultivars and two advanced selections. Examination of fruit quality traits and their temporal trends should help inform future strategies for genetic improvement.

\section{Materials and Methods}

\section{Plant materials and cultural practices}

The 10 cultivars released since 1968 and UF1 and UF2, two selections being considered for release at the time of this study, were evaluated during the 2009-2010 season. The experiment was conducted across two locations. The trial grounds of the Florida Strawberry Growers Association at Dover, FL, was the location of the UF breeding program from 1968 to 2004, whereas the Gulf Coast Research and Education Center (GCREC) at Balm, FL, has served as the base of the breeding program from 2005 to the present.

Each trial site was prepared and maintained according to current commercial practices for annual strawberry plasticulture in Florida. Pre-plant fumigant consisted of a 50:50 mixture of methyl bromide and chloropicrin. Strawberry transplants were propagated in plug trays at the GCREC greenhouse facilities from runners collected at the GCREC and were typical for trials of advanced selections. Four replicate plots (10 plants/plot) of each genotype were planted in a randomized complete block design at Dover and Balm on 14 and 15 Oct., respectively. Two d of intermittent overhead irrigation were applied for plant establishment, after which water and fertilizer were applied exclusively through the drip tape.

\section{Fruit quality traits}

Physical. Fully-ripe fruit were harvested twice weekly from the beginning of Dec. 2009 to the end of Mar. 2010 and graded in the laboratory at the GCREC. Fruit that were commercially unmarketable as a result of misshapenness, small size (less than $10 \mathrm{~g}$ ), disease, and/or surface blemishes were recorded as culls and removed, and further analyses were performed on marketable fruit only. Fruit size was calculated as the total weight in grams divided 
by the total number of marketable fruit for the entire season. On 10 Mar. 2010, internal and external color were evaluated using a handheld colorimeter (Chroma Meter CR-400; Minolta, Ramsey, NJ) with a 1-cm aperture using the variables $\mathrm{a}^{*}$ (green to red vector) and $\mathrm{L}^{*}$ (black to white vector). One representative berry per replication was chosen for color analysis. External color was measured by taking two colorimeter readings on opposite sides of the fruit halfway between the calyx and tip. Internal color was measured by slicing the berry longitudinally and taking one reading per half (two per fruit) according to Shaw (1991).

Gloss, skin toughness, and uniformity were measured on 10 Mar. and firmness was measured on 10 Mar. and 2 Apr. on a subjective 1 to 5 scale with half-point increments. Ratings were conducted using a minimum of five berries per replication and were conducted by the same individual in all cases. Gloss was visually estimated under indoor fluorescent lighting ( $1=$ dull, no gloss; $5=$ highly reflective). Skin toughness was estimated by grasping the fruit between the thumb and forefinger and rubbing the exterior of the fruit in a circular motion 10 times $(1=$ immediate breakage of the fruit epidermis; $5=$ no breakage). Uniformity was rated on the same fruit $(1=$ non-uniform surface within and among berries; $5=$ uniform surface and shape within and among berries). Firmness was rated by applying pressure to the berry using the thumb and forefinger $(1=$ minimal resistance to force; $5=$ non-yielding to force).

Chemical. Fruit from one harvest in January, February, and March were transported on the day of harvest to the USDA-ARS Citrus and Subtropical Products Laboratory in Winter Haven, FL, for chemical analyses. Fruit were homogenized using a Waring blender (Waring Products Div., Dynamics Corp. of America, New Hartford, CO) and frozen at $-20{ }^{\circ} \mathrm{C}$ for further analyses. The supernatant of thawed homogenates, centrifuged at $12,100 \times \mathrm{g}$ for $15 \mathrm{~min}$, and was analyzed for TA and SSC. For TA, $6 \mathrm{~mL}$ of the supernatant was diluted with $50 \mathrm{~mL}$ deionized water and titrated with $0.1 \mathrm{~N}$ $\mathrm{NaOH}$ to a $\mathrm{pH} 8.1$ end point using a Metrohm 808 Titrando and Metrohm 730 sample changer (Metrohm USA Inc., Westbury, NY). Soluble solids content was determined with a digital ATAGO PR-101 refractometer in the $0 \%$ to $45 \%$ Brix range (Atago Co., Tokyo, Japan).

For analysis of individual sugars and acids (Baldwin et al., 2008, 2010), $\approx 40 \mathrm{~g}$ of homogenate was extracted using $70 \mathrm{~mL} 80 \%$ ethanol/deionized water solution. The mixture was boiled for $15 \mathrm{~min}$, cooled, and filtered (Whatman \#4 filter paper, Batavia, IL). The filtered solution was brought to $100 \mathrm{~mL}$ with $80 \%$ ethanol. Ten milliliters of the filtered solution was then further filtered through a C-18 Sep-Pak (Waters/Millipore, Milford, MA), followed by a $0.45-\mu \mathrm{m}$ Millipore (SeimensMillipore, Shrewbury, MA) filter. The injection volume for high-performance liquid chromatography (HPLC) analyses of sugars and acids was $20 \mu \mathrm{L}$. Individual sugar analysis was performed using an HPLC with a refractive index detector (Perkin Elmer, Norwalk, CT) equipped with a Waters Sugar Pak column and $10^{-4} \mathrm{M}$ ethylenediaminetetraacetic acid disodium calcium salt mobile phase $\left(0.5 \mathrm{~mL} \cdot \mathrm{min}^{-1}\right.$ flow rate at $\left.90{ }^{\circ} \mathrm{C}\right)$. Analysis of individual acids was done using an Altech OA 1000 Prevail organic acid column with a flow rate of $0.2 \mathrm{~mL} \cdot \mathrm{min}^{-1}$ at $35^{\circ} \mathrm{C}$ and a mobile phase of $0.01 \mathrm{~N} \mathrm{H}_{2} \mathrm{SO}_{4}$ using a Perkin Elmer Series 200 autosampler (Waltham, MA), a Spectra System P4000 pump, and a Spectra System ultraviolet 6000 LP detector (Thermo Fisher Scientific, Waltham, MA) (Baldwin et al., 2008, 2010).

\section{Statistical analyses}

Analyses of variance of physical traits were performed using general linear models with genotype, location, block (nested within locations), and the genotype $\times$ location interaction as fixed effects. When the genotype $x$ location interaction was significant (F-test, $\alpha=$ $0.05)$, the variables were analyzed separately by location; otherwise, the interaction was dropped from the model and the data analyzed for Balm and Dover collectively. For the subjective measures of firmness, gloss, skin toughness, and uniformity ( 1 to 5 scales), residuals were examined and determined to be about normal; no further improvements could be gained through standard transformations.

To evaluate chemical traits with repeated evaluations over 3 months, correlations among measurements made on the same experimental unit were modeled using a first-order autoregressive covariance structure. The full model included genotype, location, block (nested within locations), month, and all possible interactions. Like with physical traits, specific analyses within locations and/or months were performed contingent on the significance level of the corresponding interactions (F-test, $\alpha=0.05$ ).

Using first-order models, each characteristic was regressed on the year of release of the cultivars and prospective year of release for selections. The slope associated with this variable was considered an estimate of the long-term annual change in each trait. The models also included a dichotomous variable to account for the variability introduced by the two locations in the study $(0=$ Balm, $1=$ Dover).

Statistical analyses were performed using SAS software (Version 9.2.; SAS Institute, Cary, NC). As a result of the multiple factors involved in this study (genotypes, locations, and months) and the unbalanced nature of the data, least square means (LS-Means) are reported throughout this manuscript. LSMeans are within-group (genotype) means appropriately adjusted for the other effects in the model (SAS/STAT User's Guide). LSMeans were equal to or closely approximate mean values except where missing data led to unbalanced numbers of replications. All pairwise comparisons of LS-Means were done using Fisher's least significant difference procedure with $\alpha=0.05$.

\section{Results and Discussion}

\section{Fruit quality traits}

Physical. Fruit size varied dramatically from $30.8 \mathrm{~g}$ for 'Elyana' to $16.2 \mathrm{~g}$ for 'Dover' at Balm and from $28.3 \mathrm{~g}$ for UF2 to $16.6 \mathrm{~g}$ for 'Dover' at Dover (Table 1). A linear regression of fruit size on year of release revealed an average gain of $2.6 \mathrm{~g}$ per year since 1975 for the cultivars and selections tested $\left(R^{2}=0.44\right)$. Coefficients of determination for regressions on year of release were less than 0.08 for other traits with the exception of culls $\left(R^{2}=0.30\right)$ and uniformity $\left(R^{2}=0.25\right)$. The regression for culls indicated an average reduction in culls of $0.5 \%$ per year since 1975 (Fig. 1.). At Balm, 'Florida Radiance' had the lowest cull rate $(12.3 \%)$, whereas 'Dover' had the highest $(52.5 \%)$. Selection UF1 had the highest fruit uniformity score (3.7), whereas 'Dover' had the lowest (1.8) across both locations. Two genotypes, 'Elyana' and UF2, were selected specifically for cultivation under protective structures as a result of their susceptibility to surface cracking and misshapenness under open-field conditions. When these genotypes were removed from the analysis, the $R^{2}$ value for the regression of uniformity on year of release increased to 0.36 .

In the UF strawberry breeding program, increased fruit size and uniformity and decreased cull rate have been important traits for selection. Larger fruit sizes are not only attractive to consumers, but also result in increased harvesting efficiency. Wide daily and seasonal temperature variations, freezes, and precipitation occur regularly in westcentral Florida during the growing season. These conditions reduce fruit quality through uneven pollination, which results in misshapen fruit and promote surface damage and diseases, resulting in cull fruit and reduced fruit uniformity. Although 'Florida Elyana' possesses large fruit size, its marketable yields are reduced by its susceptibility to rain damage and misshapenness in the open field compared with 'Florida Radiance', which has high marketable yields (Chandler et al., 2009a, 2009b). Fruit size and low cull rate are certainly important traits for industry acceptance, but they are also relatively easy to select in the course of breeding through rapid visual observations in the field. Therefore, improvements in these traits over time are expected and are consistent with our results.

Attempts have also been made through breeding to increase the redness of the internal flesh. We assume that increased internal flesh color is desirable to consumers, and it has been shown that color in many foods can even affect consumers' perceptions of flavor (Jaros and Rohm, 2001). In this study, there was a large and highly significant Pearson correlation for $\mathrm{a}^{*}$ and $\mathrm{L}^{*}$ values $(r=-0.91, P<0.0001)$, indicating a positive relationship between redness and darkness of the internal flesh. Therefore, only a* values are reported (Table 1). Two early releases, 'Florida Belle' (1975) and 'Dover' (1979), had $\mathrm{a}^{*}$ values of 16.1 and 18.5 , respectively. 
Table 1. Least square means and mean separations for physical fruit quality traits of University of Florida strawberry cultivars and advanced selections. ${ }^{2}$

\begin{tabular}{|c|c|c|c|c|c|c|c|c|c|c|c|c|c|c|c|c|c|c|c|c|c|}
\hline \multirow{2}{*}{$\begin{array}{l}\text { Cultivar/ } \\
\text { selection }\end{array}$} & \multirow{2}{*}{$\begin{array}{l}\text { Yr of } \\
\text { release }\end{array}$} & \multicolumn{2}{|c|}{$\begin{array}{c}\text { Fruit size } \\
(\mathrm{g})\end{array}$} & \multicolumn{2}{|c|}{ Culls (\%) } & \multicolumn{2}{|c|}{$\begin{array}{c}\text { External } \\
\text { lightness } \\
\left(\mathrm{L}^{*}\right) \\
\end{array}$} & \multicolumn{2}{|c|}{$\begin{array}{c}\text { External } \\
\text { redness } \\
\left(\mathrm{a}^{*}\right)\end{array}$} & \multicolumn{2}{|c|}{$\begin{array}{l}\text { Internal } \\
\text { redness } \\
\left(\mathrm{a}^{*}\right)\end{array}$} & \multicolumn{2}{|c|}{$\begin{array}{l}\text { Firmness } 10 \\
\text { Mar. }(1-5)^{\mathrm{y}}\end{array}$} & \multicolumn{2}{|c|}{$\begin{array}{l}\text { Firmness } 2 \\
\text { Apr. }(1-5)^{\mathrm{y}}\end{array}$} & & $\begin{array}{l}\text { oss } \\
-5)^{\mathrm{x}}\end{array}$ & \multicolumn{2}{|c|}{$\begin{array}{c}\text { Skin } \\
\text { toughness } \\
(1-5)^{\mathrm{w}}\end{array}$} & \multicolumn{2}{|c|}{$\begin{array}{c}\text { Uniformity } \\
(1-5)^{\mathrm{v}}\end{array}$} \\
\hline & & \multicolumn{6}{|c|}{ Balm } & \multicolumn{14}{|c|}{ Balm and Dover } \\
\hline UF2 & $2012^{\mathrm{u}}$ & 29.4 & $a b^{t}$ & 33.7 & $\mathrm{~cd}$ & 35.9 & cd & 36.0 & $\mathrm{a}$ & 20.4 & $\mathrm{~cd}$ & 3.3 & $\mathrm{c}$ & 2.5 & de & 3.9 & $\mathrm{abc}$ & 4.3 & $\mathrm{bc}$ & 2.9 & bcd \\
\hline Radiance & 2008 & 28.5 & $\mathrm{~b}$ & 12.3 & $\mathrm{f}$ & 33.1 & de & 35.5 & $\mathrm{a}$ & 24.2 & $\mathrm{bc}$ & 3.7 & $\mathrm{bc}$ & 3.0 & $\mathrm{bc}$ & 3.9 & $a b c$ & 4.7 & $a b$ & 3.3 & $a b$ \\
\hline Elyana & 2008 & 30.8 & $\mathrm{a}$ & 36.5 & $\mathrm{bc}$ & 35.6 & $\mathrm{~cd}$ & 36.5 & a & 19.1 & $\mathrm{~d}$ & 4.3 & $\mathrm{a}$ & 3.9 & $\mathrm{a}$ & 3.5 & $\mathrm{~cd}$ & 4.8 & $a b$ & 2.8 & bcde \\
\hline Winter Dawn & 2005 & 20.7 & $\mathrm{e}$ & 38.3 & b & 35.2 & cde & 36.2 & $\mathrm{a}$ & 20.7 & $\mathrm{~cd}$ & 1.6 & e & 2.1 & $\mathrm{e}$ & 4.1 & $\mathrm{a}$ & 3.4 & $\mathrm{~d}$ & 3.2 & $a b c$ \\
\hline Earlibrite & 2000 & 24.4 & $\mathrm{~cd}$ & 39.4 & $\mathrm{~b}$ & 37.5 & $a b c$ & 36.0 & $\mathrm{a}$ & 28.0 & b & 3.4 & $\mathrm{c}$ & 3.1 & bc & 3.7 & abcd & 3.8 & $\mathrm{~cd}$ & 3.0 & bed \\
\hline Rosa Linda & 1996 & 18.8 & fg & 32.1 & $\mathrm{~d}$ & 37.1 & $\mathrm{bc}$ & - & $\mathrm{c}^{\mathrm{s}}$ & - & - & - & - & - & - & - & - & - & - & - & - \\
\hline Swt Charlie & 1992 & 17.6 & gh & 36.8 & $\mathrm{bc}$ & 40.6 & $\mathrm{a}$ & 38.4 & $\mathrm{a}$ & 17.5 & $\mathrm{~d}$ & 1.4 & e & 1.4 & $f$ & 3.9 & $a b c$ & 2.2 & $\mathrm{e}$ & 2.7 & cde \\
\hline Dover & 1979 & 16.2 & $\mathrm{i}$ & 52.5 & $\mathrm{a}$ & 31.8 & $\mathrm{e}$ & 29.6 & b & 18.5 & d & 2.2 & d & 1.5 & $\mathrm{f}$ & 3.8 & abcd & 2.4 & $\mathrm{e}$ & 1.8 & f \\
\hline \multirow[t]{2}{*}{ Florida Belle } & 1975 & 19.7 & ef & 37.6 & $\mathrm{~b}$ & 36.1 & $\mathrm{~cd}$ & 37.5 & $\mathrm{a}$ & 16.1 & d & 4.4 & $\mathrm{a}$ & 3.8 & $\mathrm{a}$ & 3.8 & abcd & 4.8 & $a b$ & 2.4 & de \\
\hline & & \multicolumn{6}{|c|}{ Dover } & & & & & & & & & & & & & & \\
\hline Winter Dawn & 2005 & 19.5 & cde & 45.8 & $\mathrm{bc}$ & 34.3 & cde & & & & & & & & & & & & & & \\
\hline Carmine & 2002 & 19.6 & cde & 50.5 & $a b$ & 31.6 & de & & & & & & & & & & & & & & \\
\hline Festival & 2000 & 22.4 & bc & 44.6 & bcd & 34.1 & cde & & & & & & & & & & & & & & \\
\hline Earlibrite & 2000 & 21.8 & bcd & 52.0 & $a b$ & 44.2 & $\mathrm{a}$ & & & & & & & & & & & & & & \\
\hline Rosa Linda & 1996 & - & - & - & - & - & - & & & & & & & & & & & & & & \\
\hline Sweet Charlie & 1992 & 17.6 & de & 42.6 & bcd & 39.8 & $a b$ & & & & & & & & & & & & & & \\
\hline Dover & 1979 & 16.6 & e & 62.9 & $\mathrm{a}$ & 30.4 & e & & & & & & & & & & & & & & \\
\hline Florida Belle & 1975 & 21.1 & $\mathrm{~cd}$ & 39.0 & bed & 37.6 & $\mathrm{bc}$ & & & & & & & & & & & & & & \\
\hline$R_{\mathrm{YR}}^{2}{ }^{\mathrm{r}}$ & & \multicolumn{2}{|c|}{0.44} & \multicolumn{2}{|c|}{0.30} & \multicolumn{2}{|c|}{0.01} & \multicolumn{2}{|c|}{0.17} & \multicolumn{2}{|c|}{0.14} & \multicolumn{2}{|c|}{0.02} & \multicolumn{2}{|c|}{0.06} & & 01 & \multicolumn{2}{|c|}{0.08} & \multicolumn{2}{|c|}{0.25} \\
\hline
\end{tabular}

${ }^{\mathrm{z}}$ For traits with non-significant genotype $\times$ location interactions $(P>0.05)$, data are combined across sites.

${ }^{\mathrm{y}} 1=$ minimal resistance to force; 5 = non-yielding to force.

${ }^{\mathrm{x}} 1=$ dull, no gloss; $5=$ highly reflective.

${ }^{\mathrm{w}} 1=$ immediate breakage of the fruit epidermis; $5=$ no breakage.

${ }^{\mathrm{v}} 1=$ non-uniform surface within and among berries; 5 = uniform surface and shape within and among berries.

"Projected year of release.

${ }^{\mathrm{t}}$ Means within a column the same letter are not significantly different using least significant difference at $P<0.05$.

${ }^{s}$ Least squares means not estimable as a result of insufficient or unbalanced replication.

${ }^{\mathrm{r}} R^{2}$ statistics from regressions of horticultural traits on year of release.

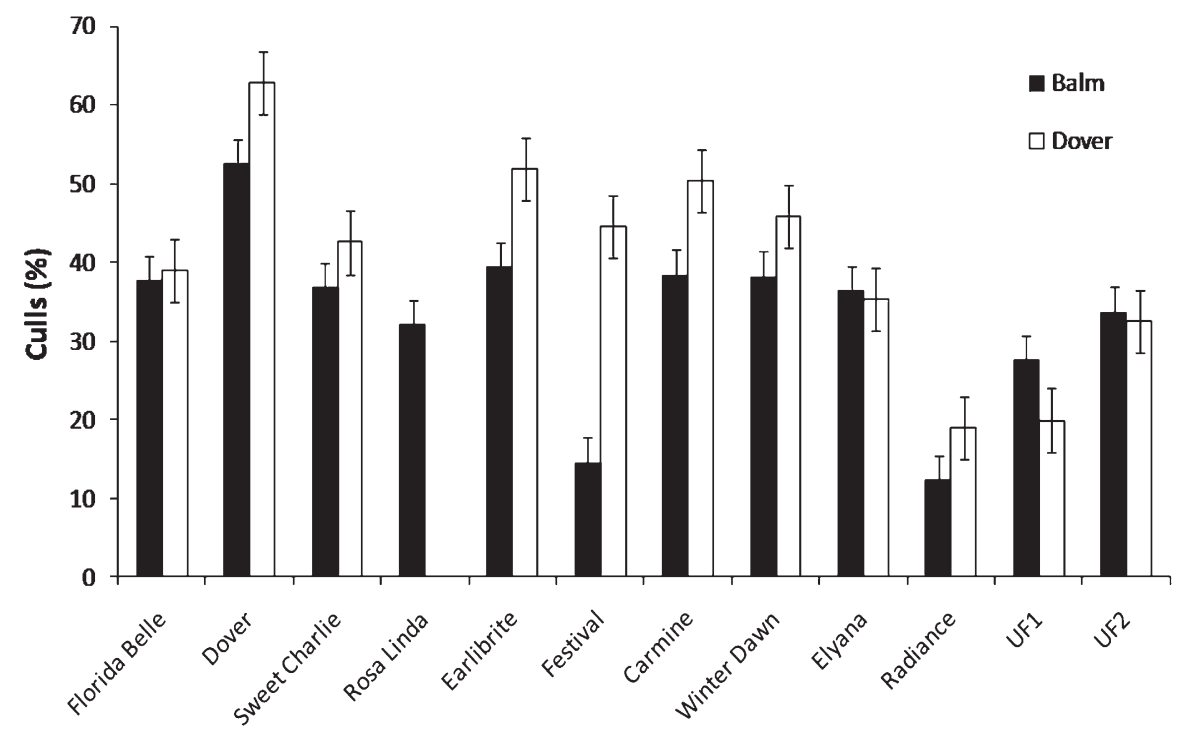

Fig. 1. Percentage of cull fruit during the 2009-2010 season from a trial of University of Florida strawberry cultivars and advanced selections (shown by order of cultivar release date) conducted at two locations. Bars represent sEs.

The cultivars Festival (2000), Earlibrite (2000), and Carmine (2002) had higher a* values of $27.0,28.4$, and 34.7 , respectively, indicating more intense color. However, these increases were not sustained in later cultivars and selec- tions but rather decreased (Table 1). Selection for internal color became secondary to selection for earliness, fruit size, firmness, and flavor. Also, negative genetic correlations between internal flesh color and other traits may be present in the breeding program and should be examined in future studies. Shaw (1991) reported weak and/or insignificant genetic correlations between internal and external color measures in strawberries, indicating that internal and external redness are conditioned by different genes. Therefore, improving internal redness while avoiding external flesh that is overly dark should be possible.

Chemical. Differences among the cultivars and selections for SSC, TA, and SSC/TA were significant as were the genotype $\times$ location interactions (Table 2). Values of SSC in almost all cultivar $\times$ location combinations were highest in February and lowest in March, which may be partly the result of increasing temperatures in March. This is consistent with late-season decreases in soluble solids seen in previous studies (Jouquand et al., 2008). There was no clear association with any of these traits and year of release $\left(R^{2} \leq 0.09\right)$. The SSC/TA ratio ranged widely among genotypes from a high of 15.6 for 'Florida Belle' in February at Dover to a low of 6.4 for 'Winter Dawn' in January at Balm. The cultivars Elyana, Florida Belle, and selection UF1 had the highest ratios across locations and months, whereas cultivars Dover and Winter Dawn had the lowest ratios.

A previous examination of UF strawberry cultivars and advanced selections showed that $\mathrm{SSC} / \mathrm{TA}$ was a strong indicator of sensory 
Table 2. Least square means and mean separations for soluble solids content (SSC), titratable acidity (TA), and the SSC/TA ratio of University of Florida strawberry cultivars and advanced selections sampled in January, February, and March.

\begin{tabular}{|c|c|c|c|c|c|c|c|c|c|c|c|c|c|c|c|c|c|c|c|}
\hline \multirow{4}{*}{$\begin{array}{l}\text { Cultivar/ } \\
\text { selection }\end{array}$} & \multirow{3}{*}{$\begin{array}{l}\mathrm{Yr} \text { of } \\
\text { release }\end{array}$} & \multicolumn{6}{|c|}{ SSC (\%) } & \multicolumn{6}{|c|}{ TA (\%) } & \multicolumn{6}{|c|}{$\mathrm{SSC} / \mathrm{TA}$} \\
\hline & & \multicolumn{2}{|c|}{ January } & \multicolumn{2}{|c|}{ February } & \multicolumn{2}{|c|}{ March } & \multicolumn{4}{|c|}{ February } & \multicolumn{2}{|c|}{ March } & \multicolumn{2}{|c|}{ January } & \multicolumn{2}{|c|}{ February } & \multicolumn{2}{|c|}{ March } \\
\hline & & \multicolumn{6}{|c|}{ Balm } & \multicolumn{6}{|c|}{ Balm } & \multicolumn{6}{|c|}{ Balm } \\
\hline & $2012^{z}$ & 9.2 & $a^{y}$ & 10.6 & $\mathrm{ab}$ & 6.4 & $\mathrm{~cd}$ & 0.84 & $\mathrm{e}$ & 0.88 & $a b c$ & 0.66 & $\mathrm{bc}$ & 11.0 & $\mathrm{bc}$ & 12.0 & $\mathrm{~cd}$ & 9.8 & $\mathrm{e}$ \\
\hline Elyana & 2008 & - & $-^{x}$ & 11.3 & $\mathrm{a}$ & 7.6 & $\mathrm{a}$ & - & - & 0.74 & def & 0.62 & $\mathrm{c}$ & - & - & 15.5 & $\mathrm{a}$ & 12.2 & $a b$ \\
\hline Winter Dawn & 2005 & 6.8 & $\mathrm{e}$ & 7.1 & f & 6.2 & $\mathrm{~cd}$ & 1.06 & $\mathrm{a}$ & 0.80 & cde & 0.81 & $\mathrm{a}$ & 6.4 & $f$ & 8.9 & $\mathrm{e}$ & 7.7 & fg \\
\hline Carmine & 2002 & 7.9 & $\mathrm{~cd}$ & 8.2 & $\mathrm{e}$ & 6.0 & de & 0.87 & de & 0.98 & $\mathrm{ab}$ & 0.75 & $\mathrm{a}$ & 9.1 & $\mathrm{~d}$ & 8.5 & e & 8.0 & fg \\
\hline Rosa Linda & 1996 & 8.5 & $\mathrm{~b}$ & 9.3 & $\mathrm{~cd}$ & - & - & 0.92 & $\mathrm{~cd}$ & 0.81 & cde & - & - & 9.3 & d & 11.6 & $\mathrm{~cd}$ & - & - \\
\hline Swt Charlie & 1992 & 9.8 & $\mathrm{a}$ & 9.8 & bcd & 7.3 & $\mathrm{a}$ & 0.85 & de & 0.79 & cde & 0.67 & $\mathrm{bc}$ & 11.6 & $\mathrm{~b}$ & 12.7 & $\mathrm{bc}$ & 10.9 & $\mathrm{~cd}$ \\
\hline Dover & 1979 & 7.6 & $\mathrm{~d}$ & 8.2 & $\mathrm{e}$ & 5.6 & ef & 1.00 & $a b$ & 1.00 & $\mathrm{a}$ & 0.80 & $\mathrm{a}$ & 7.6 & $\mathrm{e}$ & 8.2 & $\mathrm{e}$ & 7.0 & g \\
\hline \multirow[t]{2}{*}{ Florida Belle } & 1975 & 9.6 & $\mathrm{a}$ & 9.8 & bcd & 6.7 & $\mathrm{bc}$ & 0.72 & $\mathrm{f}$ & 0.68 & ef & 0.54 & de & 13.4 & $\mathrm{a}$ & 14.6 & $a b$ & 12.3 & $\mathrm{ab}$ \\
\hline & & \multicolumn{6}{|c|}{ Dover } & \multicolumn{6}{|c|}{ Dover } & \multicolumn{6}{|c|}{ Dover } \\
\hline UF2 & 2012 & 9.9 & $\mathrm{~b}$ & 10.8 & $\mathrm{~b}$ & 6.8 & de & 0.83 & ef & 0.78 & $a b$ & 0.55 & $\mathrm{bc}$ & 12.0 & $a b$ & 13.9 & $\mathrm{~b}$ & 12.2 & $\mathrm{bc}$ \\
\hline Carmine & 2002 & 8.6 & de & 9.2 & $\mathrm{c}$ & 6.9 & $\mathrm{~cd}$ & 0.91 & $\mathrm{~cd}$ & 0.85 & $\mathrm{a}$ & 0.63 & $a b$ & 9.4 & $\mathrm{c}$ & 10.9 & d & 11.0 & $\mathrm{~cd}$ \\
\hline Festival & 2000 & 8.3 & e & 11.7 & $\mathrm{~b}$ & 7.1 & $\mathrm{~cd}$ & 0.92 & $\mathrm{c}$ & 0.77 & $a b$ & 0.68 & $\mathrm{a}$ & 9.0 & $\mathrm{~cd}$ & 14.7 & $\mathrm{ab}$ & 10.5 & $\mathrm{~d}$ \\
\hline Earlibrite & 2000 & 8.8 & cde & 11.7 & $\mathrm{~b}$ & 8.1 & $a b$ & 0.77 & fg & 0.79 & $a b$ & 0.58 & $a b c$ & 11.5 & $\mathrm{~b}$ & 15.1 & $a b$ & 14.0 & $a b$ \\
\hline Rosa Linda & 1996 & - & - & - & - & - & - & - & - & - & - & - & - & - & - & - & - & - & - \\
\hline Sweet Charlie & 1992 & 9.8 & $\mathrm{bc}$ & 9.4 & $\mathrm{c}$ & 7.1 & bcd & 0.85 & de & 0.69 & $\mathrm{bc}$ & 0.53 & $\mathrm{bc}$ & 11.5 & $\mathrm{~b}$ & 13.4 & $\mathrm{bc}$ & 13.7 & $a b$ \\
\hline Dove & 1979 & 7.8 & ef & 7.6 & d & 5.6 & g & 0.98 & $a b$ & 0.95 & $\mathrm{a}$ & 0.72 & $\mathrm{a}$ & 7.9 & de & 7.8 & $\mathrm{e}$ & 7.8 & f \\
\hline Florida Belle & 1975 & 8.8 & cde & 9.3 & c & 6.3 & ef & 0.69 & $\mathrm{~h}$ & 0.60 & $\mathrm{c}$ & 0.49 & $\mathrm{c}$ & 12.8 & $a b$ & 15.6 & $\mathrm{a}$ & 12.9 & b \\
\hline$R^{2}{ }_{\mathrm{YR}}{ }^{\mathrm{w}}$ & & \multicolumn{2}{|c|}{0.03} & \multicolumn{2}{|c|}{0.02} & \multicolumn{2}{|c|}{0.08} & \multicolumn{2}{|c|}{0.00} & \multicolumn{2}{|c|}{0.03} & 0. & & 0. & & & & 0. & \\
\hline
\end{tabular}

${ }^{\mathrm{z}}$ Projected year of release.

${ }^{\mathrm{y}}$ Means within a column with the same letter are not significantly different using least significant difference at $P<0.05$.

${ }^{\mathrm{x}}$ Least squares means not estimable resulting from insufficient or unbalanced replication.

${ }^{\mathrm{w}} R^{2}$ statistics from regressions of traits on year of release.

panel ratings with high ratios associated with increased perception of sweetness (Jouquand et al., 2008), which is consistent with the results of other studies on strawberry flavor (PelayoZaldivar et al., 2005; Wozniak et al., 1997). Because we have shown significant genetic variation in UF germplasm for SSC, TA, and SSC/TA and because these have been associated with taste preference, it should be possible to breed for improved flavor by targeting optimal values of these traits in the breeding program.

Month-to-month variation in individual sugars and acids largely mirrored that of SSC and TA (Table 3). Citric acid, however, was very stable across both months and environments, because genotype $\times$ month and genotype $\times$ location interactions were not significant $(P>0.05)$. Citric acid content varied from $0.56 \%$ for UF1 to $1.05 \%$ for 'Dover'. On the other hand, the malic acid content of the cultivars and selections was influenced by month and location. In all environments and months, 'Carmine' had the highest malic acid content with a maximum of $0.83 \%$ in January at Balm. By contrast, 'Dover' has the highest citric acid content $(1.05 \%)$ but ranged in malic acid content from $0.10 \%$ to $0.20 \%$ across months and locations. On occasion, 'Carmine' has been noted as having an astringent mouth feel, which could be from high malic acid, a combination of high malic and citric acids, or other phenolic compounds in the fruit. Although phenolic compounds, specifically tannins, are known to induce the feeling of astringency, studies have shown that malic acid in water can induce stronger intensity responses for astringency than for sourness (Straub, 1989), and a malic acid/citric acid mix can also induce astringency (Rubico and McDaniel, 1992). The cultivar Winter Dawn had the second highest malic acid content in four of six cases and has also been noted as having a sour and astringent taste in sensory panels (Plotto et al., 2010).

Fructose and glucose contents were highly influenced by month. Nevertheless, there was a significant impact of genotype on sugar contents (Table 3). Elyana was the cultivar with the highest fructose and glucose content in all cases; fructose ranged from 3.24\% in March at Balm to $6.29 \%$ in February at Dover. Sucrose contents were measured but the data fell outside of the range of values published for strawberry in other studies; therefore, the data were regarded as suspect until further evaluations and are not presented here. Glucose and fructose contents were highly correlated with one another $(r=0.92, P<0.0001)$ and were also highly correlated with SSC $(r=0.87, P<0.0001$ and $r=0.76, P<0.0001$, respectively). These correlations confirm that SSC serves as a reliable approximation of glucose and fructose content for UF germplasm. Shaw (1988) reported that total sugars accounted for an average of $66 \%$ of SSC, and other studies have reported correlations between total sugars and SSC ranging from $r=0.82$ to $r=0.91$ (Kallio et al., 2000; Pelayo-Zaldivar et al., 2005)

\section{Conclusions}

Genotype explained a significant portion of variation in all traits measured in this study. For some traits such as fruit size and cull rate, significant gains from recurrent selection are apparent in the breeding program. These remain very important traits for industry acceptance, and selection pressure for these traits must be maintained. Internal redness is an example of a trait for which progress was observed early in the breeding program but gains were not sustained. This trend may have resulted from a lack of intentional selection for this trait compared with other important traits. Attention to this trait should be renewed, and genetic relationships between internal color and other important traits should be examined in future studies.

For chemical traits that affect flavor, no obvious patterns were discernable over time. These results may be reflective of various factors, including differences in the heritability of these traits, environmental variation, the feasibility of selection, and breeding priorities. Although fruit size is readily selected in the field, sugars and organic acids are selected only indirectly by tasting a small proportion of the breeding population. Perhaps instrumental measures can help guide selection for better flavor. The data gathered thus far indicate that increasing the SSC/TA ratio through breeding should generally result in improved flavor perception. Sensory evaluations of advanced selections will 
Table 3. Least square means and mean separations for individual sugars and acids of University of Florida strawberry cultivars and advanced selections sampled in January, February, and March. ${ }^{\mathrm{z}}$

\begin{tabular}{|c|c|c|c|c|c|c|c|c|c|c|c|c|c|c|c|c|c|c|c|}
\hline \multirow{3}{*}{$\begin{array}{l}\text { Cultivar/ } \\
\text { selection }\end{array}$} & \multirow{3}{*}{$\begin{array}{c}\text { Yr of } \\
\text { release }\end{array}$} & Citric acid (\%) & \multicolumn{5}{|c|}{ Malic acid (\%) } & \multicolumn{6}{|c|}{ Fructose $(\%)$} & \multicolumn{6}{|c|}{ Glucose $(\%)$} \\
\hline & & $\overline{\text { January/February/March }}$ & \multicolumn{3}{|c|}{ February } & \multicolumn{2}{|c|}{ March } & \multicolumn{4}{|c|}{ February } & \multicolumn{2}{|c|}{ March } & \multicolumn{4}{|c|}{ February } & \multicolumn{2}{|c|}{ March } \\
\hline & & Balm and Dover & \multicolumn{5}{|c|}{ Balm } & \multicolumn{6}{|c|}{ Balm } & \multicolumn{6}{|c|}{ Balm and Dover } \\
\hline UF2 & $2012^{y}$ & $0.78 \mathrm{de}^{\mathrm{x}}$ & 0.35 & 0.27 & $\mathrm{~b}$ & 0.17 & cde & 3.41 & $\mathrm{bc}$ & 3.67 & $\mathrm{bc}$ & 2.26 & $\mathrm{~cd}$ & 3.65 & $\mathrm{bc}$ & 4.22 & $\mathrm{~b}$ & 2.49 & $\mathrm{~d}$ \\
\hline UF1 & $2011^{\mathrm{y}}$ & $0.56 \mathrm{f}$ & 0.34 & 0.17 & de & 0.19 & $\mathrm{~cd}$ & 3.40 & bc & 3.63 & bcd & 2.63 & bc & 3.65 & bc & 3.95 & bcd & 2.91 & bc \\
\hline Radiance & 2008 & $0.78 \mathrm{de}$ & 0.31 & 0.11 & ef & 0.21 & $\mathrm{c}$ & 2.42 & de & 2.64 & $\mathrm{e}$ & 1.75 & $\mathrm{e}$ & 2.61 & ef & 2.83 & fg & 1.96 & ef \\
\hline Elyana & 2008 & 0.79 & $-^{\mathrm{w}}$ & 0.14 & def & 0.13 & ef & - & - & 4.80 & $\mathrm{a}$ & 3.24 & $\mathrm{a}$ & 4.59 & $\mathrm{a}$ & 5.21 & $\mathrm{a}$ & 3.52 & $\mathrm{a}$ \\
\hline Winter Dawn & 2005 & $0.95 \quad \mathrm{~b}$ & 0.60 & 0.16 & de & 0.28 & $\mathrm{~b}$ & 2.26 & e & 2.92 & de & 2.11 & de & 2.27 & $\mathrm{f}$ & 2.74 & fg & 2.20 & e \\
\hline Carmine & 2002 & 0.93 & 0.83 & 0.52 & $\mathrm{a}$ & 0.37 & $\mathrm{a}$ & 3.03 & bcd & 2.86 & $\mathrm{e}$ & 1.77 & $\mathrm{e}$ & 3.00 & de & 3.05 & ef & 2.09 & $\mathrm{e}$ \\
\hline Festival & 2000 & $0.84 \mathrm{~cd}$ & 0.49 & 0.26 & bc & 0.20 & $\mathrm{c}$ & 2.84 & cde & 3.81 & $\mathrm{bc}$ & 2.56 & $\mathrm{bc}$ & 3.01 & $\mathrm{~d}$ & 4.19 & bc & 2.64 & $\mathrm{~cd}$ \\
\hline Earlibrite & 2000 & 0.91 & 0.22 & 0.11 & ef & 0.09 & $\mathrm{f}$ & 3.69 & $a b$ & 4.26 & $a b$ & 2.70 & $\mathrm{~b}$ & 3.50 & $\mathrm{bc}$ & 4.36 & $\mathrm{~b}$ & 2.75 & bcd \\
\hline Rosa Linda & 1996 & $0.97 \mathrm{ab}$ & 0.54 & 0.20 & $\mathrm{~cd}$ & - & - & 3.56 & $\mathrm{abc}$ & 3.29 & cde & - & - & 3.55 & $\mathrm{bc}$ & 3.46 & de & - & - \\
\hline Swt Charlie & 1992 & $0.75 \mathrm{de}$ & 0.16 & 0.12 & ef & 0.17 & cde & 4.36 & $\mathrm{a}$ & 3.61 & bcd & 2.63 & bc & 4.00 & $a b$ & 3.66 & $\mathrm{~cd}$ & 2.94 & $\mathrm{~b}$ \\
\hline Dover & 1979 & $1.05 \mathrm{a}$ & 0.20 & 0.13 & def & 0.14 & def & 2.85 & cde & 2.72 & $\mathrm{e}$ & 1.89 & de & 2.66 & de & 2.56 & $\mathrm{~g}$ & 1.80 & $\mathrm{f}$ \\
\hline \multirow[t]{2}{*}{ Florida Belle } & 1975 & $0.72 \mathrm{e}$ & 0.21 & 0.09 & f & 0.11 & f & 3.72 & $\mathrm{ab}$ & 4.17 & $\mathrm{ab}$ & 2.62 & bc & 3.49 & $\mathrm{c}$ & 3.95 & bcd & 2.58 & $\mathrm{~d}$ \\
\hline & & & \multicolumn{5}{|c|}{ Dover } & \multicolumn{6}{|c|}{ Dover } & & & & & & \\
\hline UF2 & 2012 & & 0.21 & 0.22 & $\mathrm{a}$ & 0.17 & bcd & 3.50 & $a b c$ & 4.32 & bcd & 2.72 & $\mathrm{bc}$ & & & & & & \\
\hline UF1 & 2011 & & 0.38 & 0.14 & bc & 0.16 & bcd & 3.61 & $a b$ & 3.52 & de & 3.03 & & & & & & & \\
\hline Radiance & 2008 & & 0.26 & 0.09 & de & 0.15 & $\mathrm{~cd}$ & 2.53 & cde & 2.67 & $\mathrm{f}$ & 1.79 & e & & & & & & \\
\hline Elyana & 2008 & & 0.24 & 0.19 & $a b$ & 0.13 & cde & 3.55 & $a b c$ & 6.29 & $\mathrm{a}$ & 3.58 & $\mathrm{a}$ & & & & & & \\
\hline Winter Dawn & 2005 & & 0.26 & 0.14 & bcd & 0.22 & $\mathrm{~b}$ & 1.83 & $\mathrm{e}$ & 2.52 & $\mathrm{f}$ & 1.90 & $\mathrm{e}$ & & & & & & \\
\hline Carmine & 2002 & & 0.33 & 0.22 & $\mathrm{a}$ & 0.28 & $\mathrm{a}$ & 2.74 & bcde & 3.03 & ef & 2.15 & de & & & & & & \\
\hline Festival & 2000 & & 0.21 & 0.20 & $a b$ & 0.19 & $\mathrm{bc}$ & 2.47 & de & 4.80 & $a b c$ & 2.50 & $\mathrm{~cd}$ & & & & & & \\
\hline Earlibrite & 2000 & & 0.10 & 0.07 & de & 0.09 & de & 3.13 & abcd & 5.29 & $a b$ & 3.25 & $a b$ & & & & & & \\
\hline Rosa Linda & 1996 & & - & - & - & - & - & - & - & - & - & - & - & & & & & & \\
\hline Sweet Charlie & 1992 & & 0.17 & 0.12 & bcd & 0.12 & cde & 4.30 & $\mathrm{a}$ & 2.88 & ef & 2.78 & bc & & & & & & \\
\hline Dover & 1979 & & 0.14 & 0.10 & cde & 0.16 & $\mathrm{~cd}$ & 2.66 & bcde & 2.35 & $\mathrm{f}$ & 1.75 & $\mathrm{e}$ & & & & & & \\
\hline Florida Belle & 1975 & & 0.12 & 0.05 & $\mathrm{e}$ & 0.08 & $\mathrm{e}$ & 3.12 & abcd & 3.65 & cde & 2.41 & $\mathrm{~cd}$ & & & & & & \\
\hline$R^{2} \mathrm{YR}^{\mathrm{v}}$ & & 0.03 & 0.32 & & & 0.1 & & 0. & & & & 0.0 & & $<0.0$ & & 0. & & 0.0 & \\
\hline
\end{tabular}

${ }^{\mathrm{z} F o r}$ traits with non-significant genotype $\times$ environment interactions $(P>0.05)$, data are combined across sites.

yProjected year of release.

${ }^{\mathrm{x}}$ Means within a column with the same letter are not significantly different using least significant difference at $P<0.05$.

wLeast squares means not estimable as a result of insufficient or unbalanced replication.

${ }^{\mathrm{v}} R^{2}$ statistics from regressions of traits on year of release.

continue to be performed to more firmly establish the optimal range for SSC/TA. Significant genotype $\times$ environment and genotype $\times$ month interactions for most fruit chemical traits demonstrate that advanced selections must be tested in multiple environments over multiple time points. It would also be valuable to determine through genetic studies whether recurrent selection could result in genotypes with greater seasonal stability for fruit chemical traits and thereby more consistent flavor. The astringency character in strawberries might be worthy of further investigation by determining the respective role of organic acids and phenolic compounds.

'Strawberry Festival' is the dominant strawberry cultivar in west-central Florida, occupying over half of planted acreage at the time of this study. Therefore, it is interesting to note that this cultivar rarely had the most extreme values for any of the traits studied. This illustrates the importance of acceptable performance for many traits, not just a few, in the commercial success of a strawberry cultivar.

\section{Literature Cited}

Baldwin, E., A.K. Goodner, and A. Plotto. 2008. Interaction of volatiles, sugars and acids on perception of tomato aroma and flavor descriptors. J. Food Sci. 73:S294-S307.

Baldwin, E., A. Plotto, J. Manthey, G. McCollum, J. Bai, M. Irey, R. Cameron, and G. Luzio. 2010. Effect of Liberibacter infection (Huanglongbing disease) of citrus on orange fruit physiology and fruit/fruit juice quality: Chemical and physical analyses. J. Agr. Food Chem. 58:1247-1262.

Bayles, M.B., L.M. Verhalen, W.M. Johnson, and B.R. Barnes. 2005. Trends over time among cotton cultivars released by the Oklahoma Agricultural Experiment Station. Crop Sci. 45: 966-980.

Chandler, C.K., E.E. Albregts, J.K. Brecht, and C.M. Howard. 1997a. 'Sweet Charlie' strawberry. HortScience 32:1132-1133.

Chandler, C.K., D.E. Legard, and C.A. Sims. 1997b. 'Rosa Linda' strawberry. HortScience 32:1134-1135.

Chandler, C.K., D.E. Legard, T.E. Crocker, and C.A. Sims. 2004. 'Carmine' strawberry. HortScience 39:1496-1497.

Chandler, C.K., D.E. Legard, D.D. Dunigan, T.E. Crocker, and C.A. Sims. 2000a. 'Earlibrite' strawberry. HortScience 35:1363-1365.

Chandler, C.K., D.E. Legard, D.D. Dunigan, T.E Crocker, and C.A. Sims. 2000b. 'Strawberry Festival' strawberry. HortScience 35:1366-1367.

Chandler, C.K., B.M. Santos, N.A. Peres, C. Jouquand, and A. Plotto. 2009a. 'Florida Elyana' strawberry. HortScience 44:1775-1776.

Chandler, C.K., B.M. Santos, N.A. Peres, C. Jouquand, A. Plotto, and C.A. Sims. 2009b. 'Florida Radiance' strawberry. HortScience 44:1769-1770.

Jaros, D. and H. Rohm. 2001. Identification of sensory color optima of strawberry yogurt. J. Food Qual. 24:79-86.

Jouquand, C., C.K. Chandler, A. Plotto, and K. Goodner. 2008. A sensory and chemical analysis of fresh strawberries over harvest dates and seasons reveals factors that affect eating quality. J. Amer. Soc. Hort. Sci. 133:859-867.
Kallio, H., M. Hakala, A. Pelkkikangas, and A. Lapveteläinen. 2000. Sugars and acids of strawberry varieties. Eur. Food Res. Technol. 212:8185.

Pelayo-Zaldivar, C., S.E. Ebeler, and A.A. Kader. 2005. Cultivar and harvest date effects on flavor and other quality attributes of California strawberries. J. Food Qual. 28:78-97.

Plotto, A., V. Whitaker, and C. Chander. 2010. Eating quality of old and new university of Florida strawberry cultivars. Proc. Fla. State Hort. Soc. (in press).

Rubico, S.M. and M.R. McDaniel. 1992. Sensory evaluation of acids by free-choice profiling. Chem. Senses 17:273-289.

Shaw, D.V. 1988. Genotypic variation and genotypic correlations for sugars and organic acids of strawberries. J. Amer. Soc. Hort. Sci. 113: 770-774.

Shaw, D.V. 1991. Genetic variation for objective and subjective measures of fresh fruit color in strawberries. J. Amer. Soc. Hort. Sci. 116:894-898.

Shaw, D.V. and K.D. Larson. 2008. Performance of early-generation and modern strawberry cultivars from the University of California breeding programme in growing systems simulating traditional and modern horticulture. J. Hort. Sci. Biotechnol. 83:648-652.

Straub, A.M. 1989. Power function determination for sourness and time-intensity measurements of sourness and astrigency for selected acids. MS thesis, Oregon State University, Corvallis, OR.

Wozniak, W., B. Radajewska, A. ReszelskaSieciechowicz, and I. Dejwor. 1997. Sugars and acid content influence organoleptic evaluation of fruits of six strawberry cultivars from controlled cultivation. Acta Hort. 439:333-336. 